International Journal of Biology, Pharmacy and Allied Sciences (IJBPAS)

'A Bridge Between Caboratory and Q and

WwW.ibpas.com

SYNTHESIS AND CHARACTERIZATION OF SILVER NANOPARTICLES USING

CITRUS MAXIMA FRUIT PEEL EXTRACT AND THEIR CYTOTOXIC ACTIVITY

AGAINST CERVICAL CANCER CELL LINE (HeLa CELLS)

\title{
KAVITHA $\mathbf{S}^{1 *}$ AND ANJU $\mathrm{KU}^{2}$
}

1: Assistant Professor, Department of Biochemistry, Rathnavel Subramaniam college of Arts and Science, Coimbatore, Tamil Nadu

2: PG Department, Department of Biochemistry, Rathnavel Subramaniam college of Arts and Science, Coimbatore, Tamil Nadu, India

*Corresponding Author: Dr. Kavitha S: E Mail: kavi84msc@gmail.com

Received 23 ${ }^{\text {rd }}$ Nov. 2020; Revised 29 ${ }^{\text {th }}$ Dec. 2020; Accepted $7^{\text {th }}$ Jan. 2021; Available online $1^{\text {st }}$ Oct. 2021

https://doi.org/10.31032/IJBPAS/2021/10.10.5648

ABSTRACT

The green synthesis of nanoparticles from plant extract has been increasingly gaining popularity due to its eco-friendly nature and cost-effectiveness. In this study, Silver nanoparticles were synthesized using the fruit peel extract of Citrus maxima. The synthesized AgNPs characteristics were confirmed by using several studies includes UV-Vis spectroscopy, SEM, XRD and FTIR. The results obtained from the UV-visible spectroscopic analysis showed that the intense surface plasmon resonance band at $425 \mathrm{~nm}$ which indicates the formation of AgNPs. The morphology of AgNPs was observed under scanning electron microscopy displayed that the synthesized AgNPs have a spherical shape with an average size ranges from 38-65 $\mathrm{nm}$ in diameter. The XRD study showed that the particles were crystalline in nature, with FCC structure. FTIR indicated that the AgNPs capped with active ingredients of the fruit peel extract. The performance of fruit peel extract of Citrus maxima AgNPs in terms of inhibition of bacteria growth was studied by disc diffusion. Synthesized fruit peel extract of Citrus maxima AgNPs were found to possess enhanced antibacterial properties. The nanoparticles were assessed for their cytotoxic activity on HeLa (cervical cancer) cell line. MTT assay is colorimetric assay used for measure the cytotoxicity, the 
silver nanoparticles to inhibit the cancer cell line. The HeLa cells treated with AgNPs induce the apoptosis through DNA damage was confirmed in DNA fragmentation assay.

Keywords: Citrus maxima, fruit peel, characterization, cytotoxicity, MTT, HeLA

\section{INTRODUCTION}

Nanotechnology is the particle synthesis with minimum of one dimension in the range between $1-100 \mathrm{~nm}$, which results in high surface to volume ratios. If the particle size decreases, the ratio of surface area to volume increase and also the physical, chemical, and biological properties of the particles differ when compared to their bulk counterparts [1-3]. Metal nanoparticles exhibit physicochemical [4] magnetic and biochemical characteristics. They are used mainly in industrial and pharmaceutical applications [5]. The nanoparticles play a vital role in the field of health care, medical screening, drug delivery system, antisense, tissue biotechnology, cosmetics, applications of gene engineering, and so on [6-8].

Green synthesis is defined as the use of environmentally compatible material (materials like bacterium, fungi and plants) within the nanoparticles synthesis. The green synthesis of nanoparticles is ecofriendly, non-toxic, affordable and safe. Also, the Nanoparticle coatings are hazardous free material on their surface [912]. The nanoparticles synthesis from biologically derived extracts offers easy production with a high yield. Therefore, synthesis of nanoparticle from plant extracts was a good platform for large scale production commercially [13-15].

Silver nanoparticles exhibits excellent medical and non- medical applications when compared with other metal nanoparticles. Plants have been used for centuries for their medicinal properties. The biosynthesis of AgNPs with plant extracts has been exploited. This approach is preferred due to the minimizing of processing time which is more economical and it can be done in large scale basis too [16-20]. Nanostructured systems enhance the action of plant extract which improve the activity, reducing the required dose and probably reducing adverse side effects [21]. During nanoparticles synthesis, plant extract plays a vital role which is non- toxic and act as a reducing or capping agents [22].

Major applications of nanotechnology based medical science, mainly in the field of cancer; it forms the core of analysis activities within the worldwide. Nanoscience has been shown that silver particles have therapeutic and diagnostic applications [23, 24]. As a result, its analysis is taken into account tool of the field like polyose, tolensis, irradiation 
and biological activity were reasonable measure of approaches for the synthesis of green nanoparticles [25].

In addition the silver nanoparticles have an antimicrobial property. The antimicrobial agent has an inhibitory effect against the pathogens. The antimicrobial agents; effects of silver nanoparticles toxicity are mediated by each of silver nanoparticles and also the silver ions that released throughout contact with water or fluid. Each of these silver ions will penetrate into the living substance. The inactivation method of enzyme-membranes like phosphormannose enzyme caused denaturation of the microorganism cell [26-29].

Cancer is a neurotic condition described by unnecessary cell development and getting from loss of authority over the cell cycle and diminished apoptosis [30]. Cervical cancer is one of the most wellknown kinds of diseases around the world. While chemotherapy is one of the most broadly utilized helpful systems against cervical cancer, it likewise has a few constraints, for example, normal cell toxicity and steadily expanding opposition in disease cells. The revelation of new medications for use in alternative strategies in cancer treatment is profoundly attractive. Plants are viewed as promising from this viewpoint, since they represent to considerable wellsprings of substances with various therapeutic uses. Most cytotoxic medications are today produced from plants [31].

Citrus maxima is an edible fruit acts as a appetizer, internal organ stimulant and abdomen tonic. It is also responsible in boosting our immune system, Also it acts as an anti-aging agent. Each part of the Citrus maxima exhibits medicinal properties. The seed plays a role in curing the coughs and dyspepsia. The fruit act as cardio-tonic, prevents constipation, improve digestion and peristalsis [32-34]. In this study we developed an optimised method for synthesis of silver nanoparticle and cytotoxic study on HeLa cancer cell line from fruit peel extract of Citrus maxima.

\section{MATERIALS AND METHODS \\ PREPARATION OF Citrus maxima PEEL EXTRACT}

The fruit Citrus maxima was collected from wayanad, Kerala. Mature undamaged fruits were selected, washed thoroughly with distilled water to remove dirt and air-dried. The fruits were peeled and the peels separated from the pulp. The Fruit peel was air dried material and cut to small piece and powdered in an electric grinder.

Biosynthesis and characterization of silver nanoparticles

The sample was prepared by taking $10 \mathrm{~g}$ of powder in a $300 \mathrm{~mL}$ Erlenmeyer flask 
along with $100 \mathrm{~mL}$ of sterilized double distilled water and then boiling the mixture for $5 \mathrm{~min}$ before. The extract was filtered through Whatman filter paper no 1 and stored at $-15{ }^{\circ} \mathrm{C}$ and could be used within 1 week. The filtrate was treated with three different concentrations $(1 \mathrm{mM}, 2 \mathrm{mM}$ and $3 \mathrm{mM}$ ) and incubated it at room temperature.

\section{CHARACTERIZATION OF SILVER NANOPARTICLES}

\section{UV Spectroscopy}

Synthesis of silver nanoparticles solution with fruit peel extract may be easily observed by ultraviolet-visible (UV-Vis) spectroscopy. The bio-reduction of the $\mathrm{Ag}^{+}$ions in solutions was monitored by periodic sampling of aliquots $(1 \mathrm{~mL})$ of the aqueous component and measuring the UVVis spectra of the solution. UV-Vis spectra of these aliquots were monitored as a function of time of reaction on a Vasco 1301 spectrophotometer in $400-600 \mathrm{~nm}$ range operated at a resolution of $1 \mathrm{~nm}$.

\section{Scanning Electron Microscope (SEM)}

The pellet was subjected for SEM analysis. Thin films of the sample were prepared on a carbon coated copper grid by just dropping a very small amount of the sample on the grid; extra solution was removed using a blotting paper and then the film on the SEM grid was allowed to dry for analysis.

\section{X-ray diffraction (XRD) analysis}

The particle size and nature of the silver nanoparticle were determined using XRD. This was carried out using Shimadzu XRD$6000 / 6100$ model with $30 \mathrm{kv}, 30 \mathrm{~mA}$ at $2 \theta$ angle. X-ray powder diffraction is a rapid analytical technique primarily used for phase identification of a crystalline material and can provide information on unit cell dimensions. The analyzed material is finely ground, and average bulk composition is determined.

\section{Fourier- Transform Infrared spectroscopy (FTIR)}

The fruit peel extract were subjected to FTIR spectroscopy in the range of $450-4000$ $\mathrm{cm}-1$ at a resolution of $4 \mathrm{~cm}-1$.

\section{Anti-Bacterial activity}

The antibacterial assays were done in grampositive bacteria (Staphylococcus aureus) and gram-negative bacteria (Escherichia coli) by standard disc diffusion method. To investigate the antibacterial effect of disk diffusion method, LB broth medium was used to cultivate bacteria. Bacteria were cultured separately on agar nutrient. On the surface of each plate disc were placed containing various concentrations $(5,10$, 15, $20 \mu \mathrm{g}$ ) of $\mathrm{AgNO}_{3}$, negative controls and positive controls (antibiotics). The plates were incubated in the oven at $37^{\circ} \mathrm{C}$. And after $24 \mathrm{~h}$ the inhibition zones around the discs were measured. 
CYTOTOXICITY STUDY OF SILVER NANOPARTICLES ON HUMAN CERVICAL CANCER CELL LINE (HeLA cell)

\section{MTT Cell viability assay}

\section{Cell lines and culture condition}

The present work was carried out in HeLa (cervical cancer) cell line was obtained from National Centre for Cell Science (NCCS), Pune, India. HeLa cell line was cultured in DMEM (Dulbecco's modified of Eagle medium with L-glutamine \& 1000 $\mathrm{mg} / \mathrm{L}$ glucose) supplemented with $10 \%$ fetal bovine serum, sodium bicarbonate $(3.7 \mathrm{~g} / \mathrm{ml})$ and glucose $(4.5 \mathrm{~g})$ and in a humidified atmosphere consisting of 5\% $\mathrm{CO}_{2}$ at $37^{\circ} \mathrm{C}$

\section{Cytotoxicity of biosynthesized AgNPs}

The anticancer activities of the Ag-NPs against HeLa cell lines by using MTT assay was carried out. MTT assay method is widely used method for the detection of cell survival and growth. It is a colorimetric assay that measures the reduction of yellow 3-(4,5- dimethylthiazol-2-yl)-2,5-diphenyl tetrazolium bromide (MTT ) by mitochondrial succinate dehydrogenase. HeLa cells were seeded at a density of $4 \times$ $10^{4}$ cells $/ \mathrm{ml}$ in a volume of $0.1 \mathrm{ml}$ in 96well plates, respectively. After 24 hours, the silver nanoparticle $(50-250 \mathrm{mg} / \mathrm{ml})$ which was dissolved in a medium was added to each well and incubated for 48 hours at $37^{\circ} \mathrm{C}$ in a $\mathrm{CO}_{2}$ incubator. After the incubation, wash the cells with DMSO and trypsin. MTT solution (100 $\mu 1 /$ well, 1 $\mathrm{mg} / \mathrm{ml}$ ) was added to each well and incubated again for 24 hrs. Absorbance at $570 \mathrm{~nm}$ was detected by micro plate ELISA reader. The inhibition ratio of the cancer cells proliferation was determined as follows

Calculation Inhibition rate $(\%)=(1-$ Abs sample / Abs control) $\times \mathbf{1 0 0}$

\section{DNA fragmentation assay}

This assay was done by using agarose gel electrophoresis. Weigh out the appropriate mass of agarose into an Erlenmeyer flask. Agarose gel were prepared using a w/v percentage solution. The concentration of agarose in a gel will depend on the sizes of the DNA fragments to be separated, with most gels ranging between $0.5 \%-2 \%$. The volume of the buffer should not be greater than $1 / 3$ of the capacity of the flask. Add running buffer to the agarose-containing flask. Swirl to mix. The most common gel running buffers are TAE $(40 \mathrm{mM}$ Trisacetate, $1 \mathrm{mM}$ EDTA) and TBE (45 mM Tris- borate, $1 \mathrm{mM}$ EDTA). Melt the agarose/buffer mixture. At $30 \mathrm{~s}$ intervals, remove the flask and swirl the contents to mix well. Repeat until the agarose has completely dissolved. Add Ethidium bromide $(\mathrm{EtBr})$ to a concentration of 0.5 $\mu \mathrm{g} / \mathrm{ml}$. Alternatively, the gel may also be stained after electrophoresis in running buffer containing $0.5 \mu \mathrm{g} / \mathrm{ml} \mathrm{EtBr}$ for $15-30$ 
min, followed by destaining in running buffer for an equal length of time. Allow the Agarose to cool either on the bench top or by incubation in a $65{ }^{\circ} \mathrm{C}$ water bath. Place the gel tray into the casting apparatus. Place an appropriate comb into the gel mold to create the wells. Pour the molten Agarose into the gel mold. Allow the Agarose to set at room temperature. Remove the comb and place the gel in the gel box. When electrophoresis has completed, take the gel from the gel tray and expose the gel to uv light. This is most commonly used gel documentation system. DNA bands should show up as orange fluorescent bands.

\section{RESULT}

\section{Synthesis of silver nanoparticles}

Silver nanoparticles were prepared from an increase $\mathrm{AgNO}_{3}$ solution of $1 \mathrm{mM}, 2 \mathrm{mM}$ and $3 \mathrm{mM}$ concentration of fruit peel extract of Citrus maxima.

As a result, a brown-yellow solution was formed, indicating the formation of silver nanoparticles was shown in Figure 1. The formation and stability of silver nanoparticles formed from the plant extract was confirmed by this technique. Furthermore, the mixture was stored in the refrigerator for further studies.

\section{Characterization of silver nanoparticles}

\section{UV-spectrum}

The change in color was observed due to the absorption of light by the AgNPs solution in the UV range of $400-500 \mathrm{~nm}$. The UV-visual absorption spectrums of fruit peel extract of Citrus maxima and biosynthesized AgNPs are shown in Figure 2. The absorption of UV light by the silver nanoparticles solution is due to a phenomenon called surface plasmon resonance.

The change in colour may be due to the excitation of surface Plasmon resonance and thus indicates that the occurrence of $\mathrm{Ag}^{+}$reduction to AgNPs. The free electrons of AgNPs give rise to a surface Plasmon resonance absorbance due to the combined vibration of electrons of the metal NPs in resonance with the light waves. The good Plasmon peak result was found in $2 \mathrm{mM}$ solution showed the sharp peak at $425 \mathrm{~nm}$. For further study the $2 \mathrm{mM}$ concentration was used.

\section{Scanning Electron Microscopy}

SEM technique was employed to visualize the size and shape of silver nanoparticles. The SEM images of the AgNPs are shown in Figure 3. The formations of silver nanoparticles, as well as their morphological dimensions were demonstrated in the SEM study. From the result it was shown that the average size was 38-68 nm with inter-particle distance. The shape was relatively spherical and uniform silver nanoparticles were formed and being used as reducing and capping agents. 


\section{X-ray diffraction (XRD) analysis}

The spherical structure and phase purity of the synthesized fruit peel extract of Citrus maxima nanomaterials were identified through XRD pattern as shown in Figure 4. The diffractometer was operating at $30 \mathrm{kv}$ and $30 \mathrm{~mA}$, with a step size of $0.02^{\circ}(2 \theta)$. The scanning was done in the region of 20 to $80^{\circ}$ for $2 \theta$. In our results, the XRD patterns showed intense diffraction peaks corresponding to 111, 200 and 311 Bragg's reflection based on the fcc structure of AgNPs.

The $2 \theta$ value of the synthesized silver nanoparticles shows peaks at 37.81, 44.01 and 64.36 corresponding to the Bragg reflection 111, 200 and 311 respectively.

\section{Fourier Transform Infrared (FTIR)}

\section{Spectroscopy}

The results of FTIR analysis of this study show different stretches of bonds shown at different peaks (Figure 5, Table 1). In the fruit peel extract of Citrus maxima, the strong absorption bands at $3674.5 \mathrm{~cm}^{-1}$ and $3333.4 \mathrm{~cm}^{-1}$ are corresponds to the $\mathrm{O}-\mathrm{H}$ to the presence of water, alcohols and phenols (polyphenols).The absorption band at $2925.20 \mathrm{~cm}^{-1}$ showed the presence of carboxylic acid group. The observed peaks at 2713.8, 2363.2 and 2342.4 $\mathrm{cm}^{-1}$ correspond to the stretching and bending vibration of $\mathrm{C}-\mathrm{H}$ alkane group. The band at 1651.2 $\mathrm{cm}^{-1}$ corresponds to amide group. The band at $1597.2 \mathrm{~cm}^{-1}$ could be attributed to $\mathrm{C}=\mathrm{C}$ aromatic stretching vibrations. The band at $1651.2 \mathrm{~cm}^{-1}$ shows the presence of $\mathrm{C}-\mathrm{O}$ groups from polyols which act as both reducing and capping agent for the stability of the bioreduced silver nanoparticles. The band at $1315.22 \mathrm{~cm}^{-1}$ ad $\quad 1203.40$ $\mathrm{cm}^{-1}$ confirmed the presence of alkyl halides.

\section{Antibacterial Assay}

The present study revealed that the fruit peel extract of Citrus maxima showed potent antibacterial activity against grampositive bacteria (Staphylococcus aureus) and a gram-negative bacteria (Escherichia coli).

Green synthesis of silver nanoparticles of fruit peel extract of Citrus maxima showed very strong inhibitory actions against $S$. aureus and followed by E. coli. The diameter of inhibition zones formed for each concentration of the $\mathrm{AgNO}_{3}$ precursor added to the fruit peel extract of Citrus maxima in synthesizing Ag nanoparticles is presented in Table 2.

CYTOTOXICITY STUDY OF SILVER NANOPARTICLES ON HUMAN CERVICAL CANCER CELL LINE (HeLa CELL LINE)

\section{MTT ASSAY}

The cytotoxic studies of fruit peel extract of citrus maxima mediated synthesized silver nanoparticles against HeLa cancer cell line. 
The invitro cytotoxicity of biologically synthesized AgNPs was investigated by using MTT assay against HeLa cancer cell line with different concentrations like $5 \mu \mathrm{g}$ $\mathrm{ml}, 10 \mu \mathrm{g} \mathrm{ml}, 15 \mu \mathrm{g} \mathrm{ml}$ and $20 \mu \mathrm{g} \mathrm{ml}^{-1}$, respectively. Biologically synthesized silver nanoparticles showed cytotoxicity on the HeLa cell line with increased concentration.

The inhibitory concentration value of biosynthesized silver nanoparticles against HeLa cells was observed at different concentrations for 24 hour. From Table 3, at a high concentration level $\left(20 \mu \mathrm{g} \mathrm{ml}^{-1}\right)$ showed $36.45 \%$ of inhibition, this results shows that the cancer cells were treated with high concentration of silver nanoparticles, it exhibits high percentage of inhibition. Biologically synthesized silver nanoparticles showed high inhibitory effect against cancer cell lines.

\section{DNA FRAGMENTATION}

The HeLa cells treated with AgNPs induce the apoptosis through DNA damage was confirmed in DNA fragmentation assay. The induction of DNA single strand break is used to predict the damage of cancer cells. In the present study, the AgNPs treated cancer cells showed apoptotic fragmentation DNA. From the Figure 6, the first lane treated with control cells shows minimum fragmentation. The second lane treated with $20 \mu \mathrm{g} \mathrm{ml}^{-1}$ concentration exhibits apoptotic fragmentation. The third lane which treated with $15 \mu \mathrm{g} \mathrm{ml}^{-1}$ showed moderate fragmentation, whereas the fourth lane which treated $5 \mu \mathrm{g} \mathrm{ml} \mathrm{ml}^{-1}$ exhibit minimum apoptotic fragmentation.

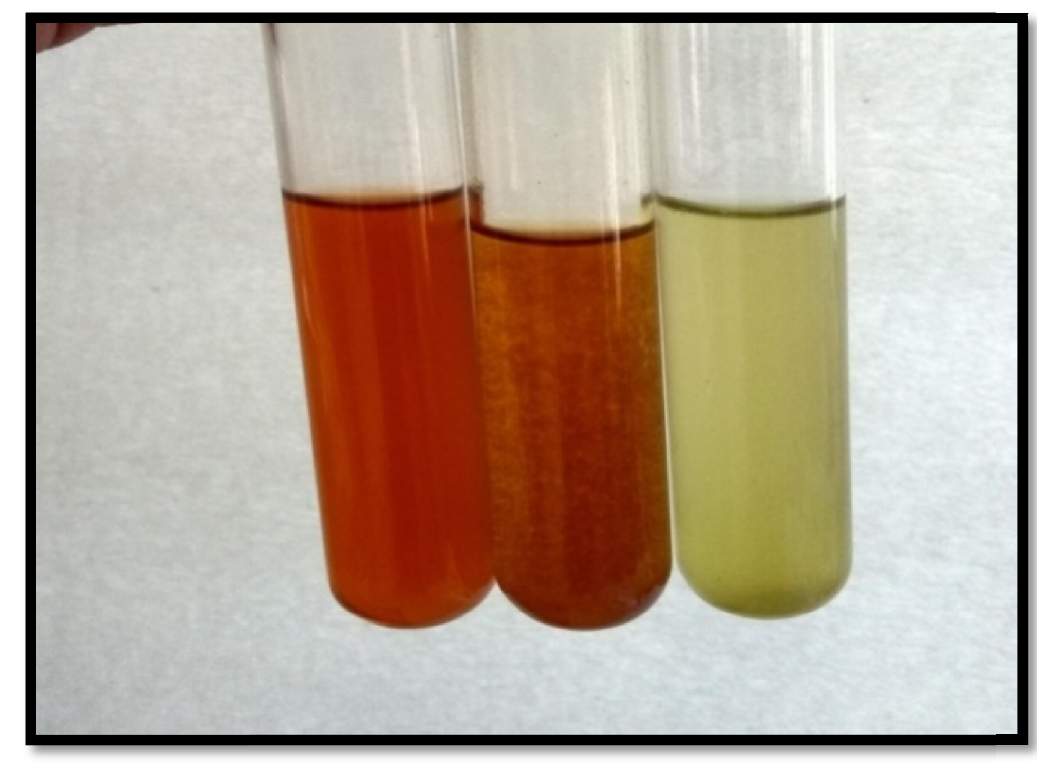

Figure 1: Synthesis of silver nanoparticles from fruit peel extract of citrus maxima 


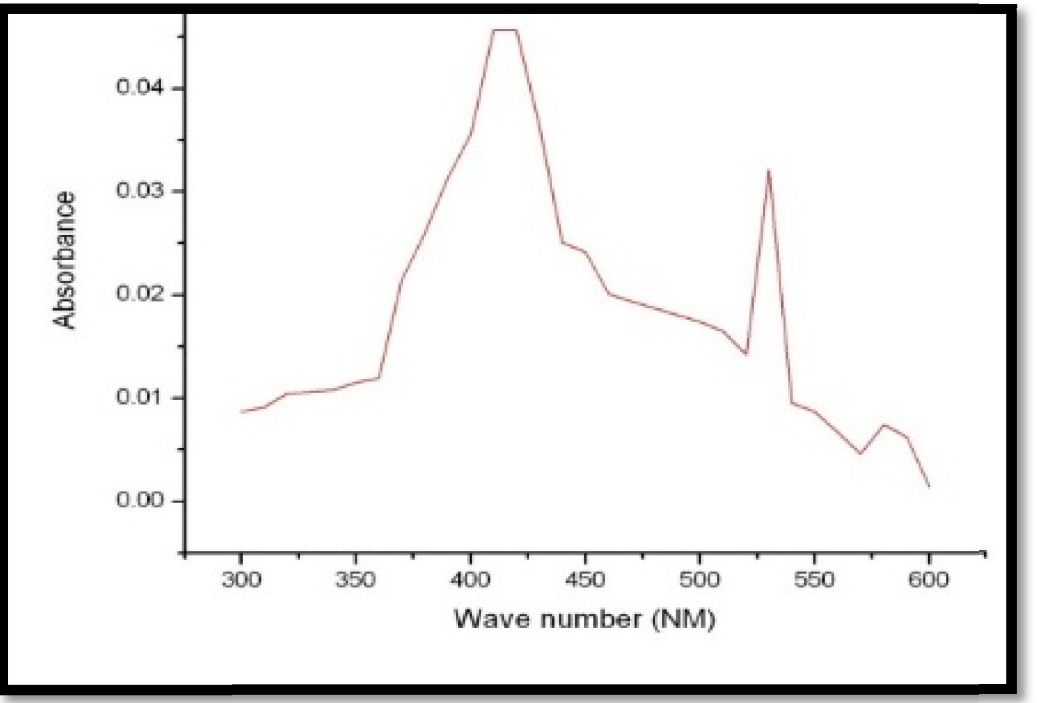

Figure 2: UV-Vis absorption spectra of $2 \mathrm{mM}$ silver nanoparticles biosynthesized by peel extract of Citrus maxima during reaction

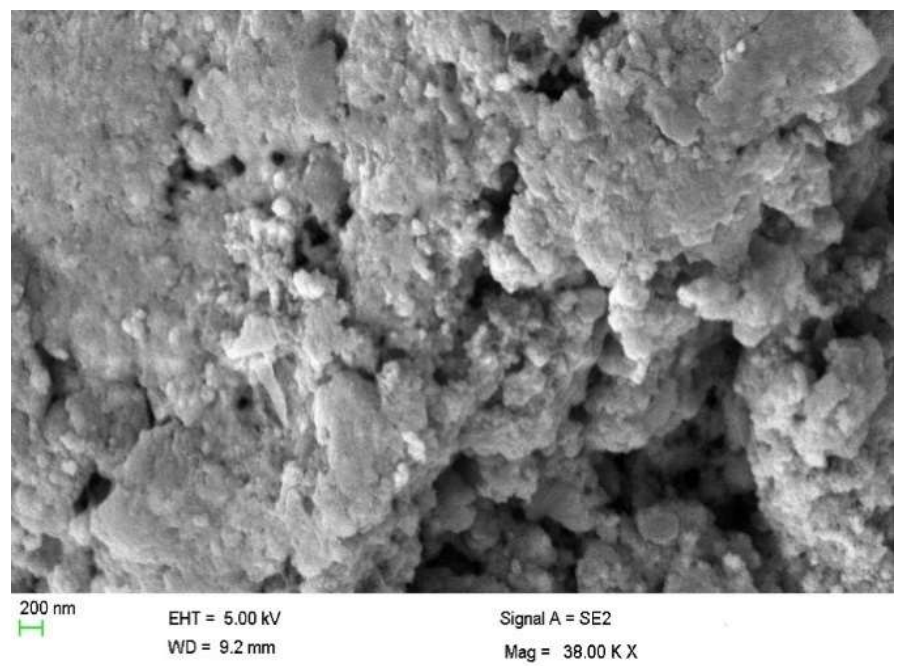

Figure 3: Identification Ag NPs synthesized from fruit peel extract of citrus maxima using scanning electron microscopy experiments

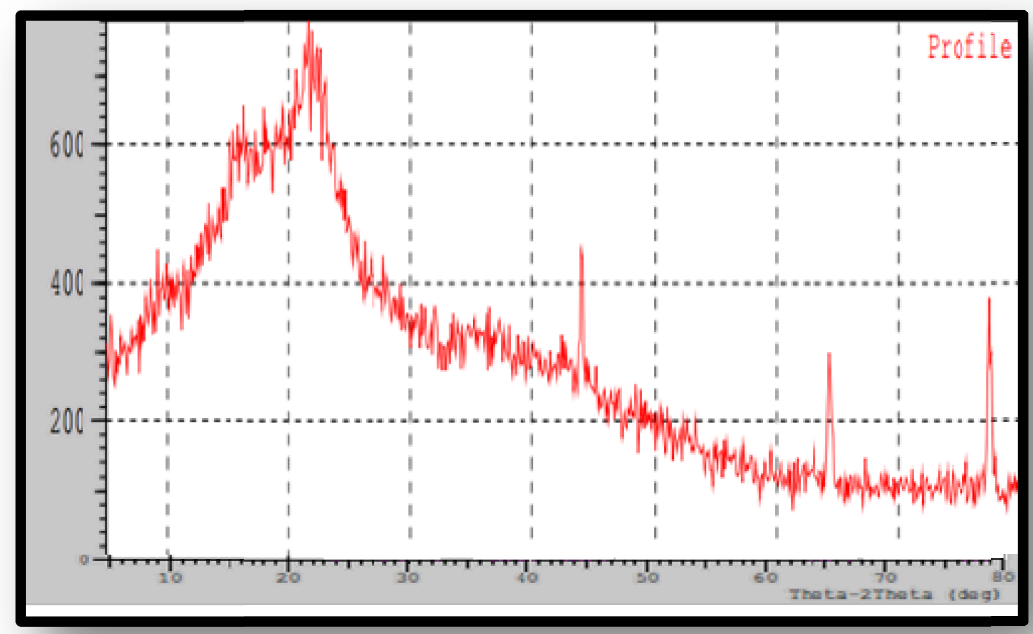

Figure 4: X- ray diffraction profile from dried silver nanoparticles biosynthesized by peel extract of Citrus maxima 


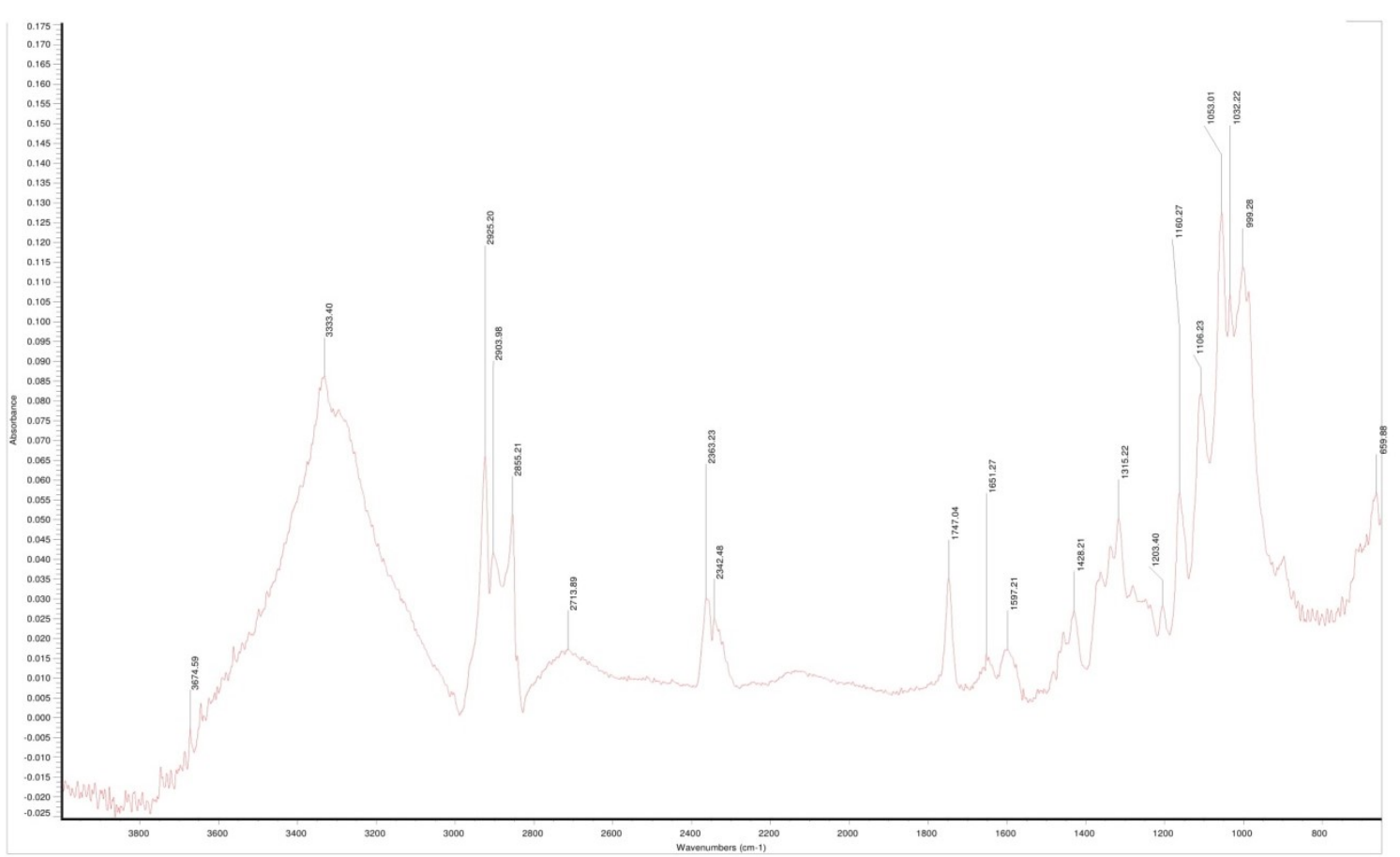

Figure 5: FTIR spectra of biosynthesized Ag NPs by peel extract of Citrus maxima

Table 1: FTIR with functional group and frequency of AgNPs synthesized from fruit peel extract of citrus maxima

\begin{tabular}{|c|c|c|}
\hline S. No & Functional group & Frequency $\left(\mathrm{Cm}^{-1}\right)$ \\
\hline 1 & Alcohol[OH] & 3674.59 \\
\hline 2 & Alcohol[OH] & 3333.40 \\
\hline 3 & Carboxylic $[\mathrm{C}=\mathrm{O}]$ & 2925.20 \\
\hline 4 & Alkane[-C-H-] & 2905.98 \\
\hline 5 & Alkane[-C-H-] & 2855.21 \\
\hline 6 & Aldehyde[C-H-] & 2713.89 \\
\hline 7 & Aldehyde[C-H-] & 2363.23 \\
\hline 8 & Aldehyde[C-H-] & 2342.48 \\
\hline 9 & $\operatorname{Ester}[C=O]$ & 1747.04 \\
\hline 10 & Amide $[\mathrm{C}=\mathrm{O}]$ & 1651.27 \\
\hline 11 & Aromatic $[\mathrm{C}=\mathrm{C}]$ & 1597.21 \\
\hline 12 & Alkyl halide[ C-F] & 1315.22 \\
\hline 13 & Alkyl halide[ C-F] & 1203.40 \\
\hline 14 & Alkyl halide[ C-F] & 1160.27 \\
\hline 15 & Alkyl halide[ C-F] & 1106.23 \\
\hline 16 & Alkyl halide[ C-F] & 1053.01 \\
\hline 17 & Alkyl halide[ C-F] & 1032.22 \\
\hline 18 & Sulfur oxide $[S=O]$ & 999.21 \\
\hline 19 & Alkyl halide[C-Cl] & 650.88 \\
\hline
\end{tabular}

Table 2: Effect of Antibacterial activity of AgNPs synthesized from fruit peel extract of citrus maxima

\begin{tabular}{|c|c|c|}
\hline & \multicolumn{2}{|c|}{ Diameter of zone of inhibition (mm) } \\
\hline Concentration of AgNPs( $\boldsymbol{\mu g})$ & S.aureus & E.coli \\
\hline 5 & 0 & 1.0 \\
\hline 10 & 2.0 & 3.0 \\
\hline 15 & 4.0 & 4.0 \\
\hline 20 & 10.0 & 4.0 \\
\hline
\end{tabular}


Table 3: Effect of Ag NPs synthesized from fruit peel extract of citrus maxima on viability of HeLA cell lines was determined by MTT assay

\begin{tabular}{|c|c|c|}
\hline Concentration $(\mu \mathrm{g} / \mathrm{ml})$ & \% Cell viability & \% Cell inhibition \\
\hline 5 & 88.57 & 11.04 \\
\hline 10 & 80.18 & 19.82 \\
\hline 15 & 68.88 & 31.12 \\
\hline 20 & 64.83 & 36.45 \\
\hline Control & 100 & 0 \\
\hline
\end{tabular}

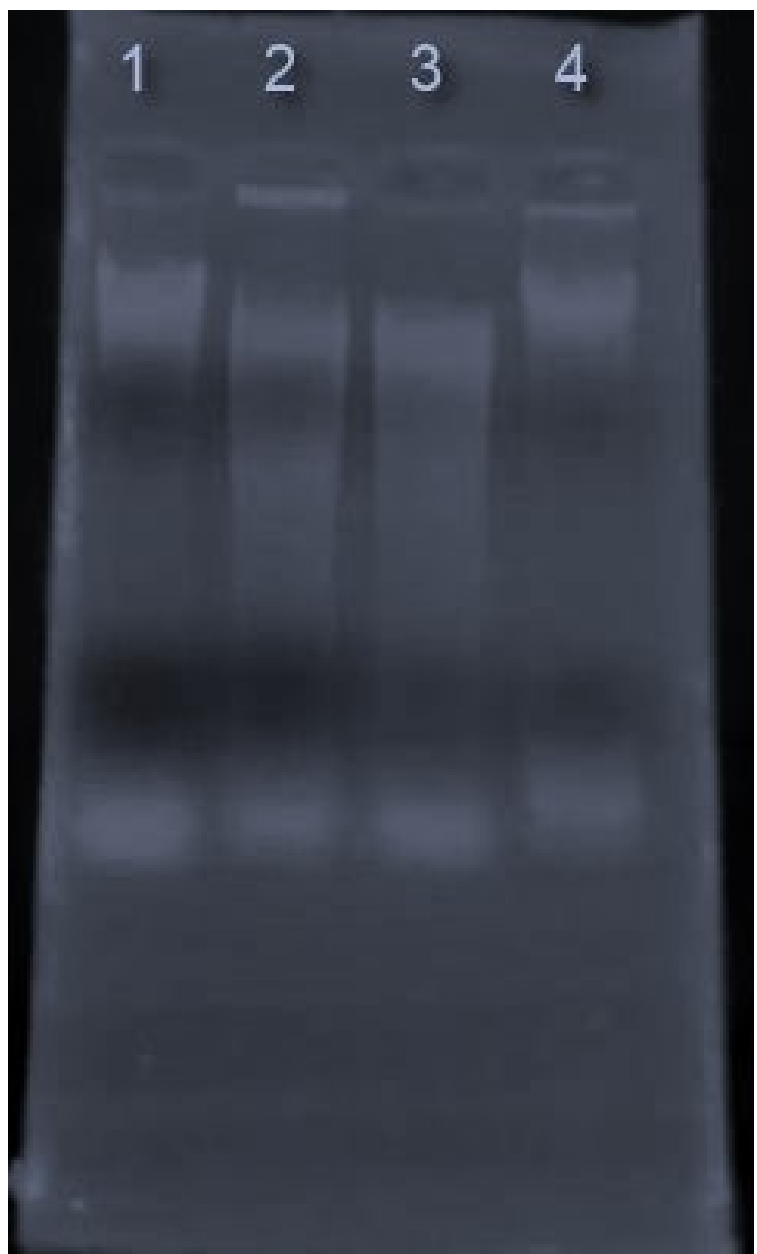

Figure 6: Ag NPs synthesized from peel extract of Citrus maxima induced DNA fragmentation Lane 1: control cell DNA, Lane 2: $20 \mu \mathrm{g} \mathrm{ml}^{-1}$, Lane 3: 15 $\mu \mathrm{g} \mathrm{ml}^{-1}$, lane 4:5 $\mu \mathrm{g} \mathrm{ml}^{-1}$ treated cell DNA

\section{DISCUSSION}

The colour change indicates the reduction of silver ion into silver particles throughout exposure to the extract [35]. Silver nanoparticles show dark yellowish-brown color is due to the surface plasmon resonance phenomenon [36]. Biosynthesis of nanoparticles by plant extracts is currently below exploitation. The biological development inspired experimental processes for the synthesis of nanoparticle is evolved into an important branch of nanotechnology.

The nanoparticles were primarily characterised by UV-Vis spectroscopy. During the reaction, reduction of $\mathrm{Ag}^{+}$ions in the aqueous solution of silver complex present in the fruit peel extracts detected by 
the UV-Vis spectroscopy. It revealed that the silver nanoparticles in the solution may be correlated with the UV-Vis spectra. As the fruit peel extracts were mixed with the aqueous solution of the silver ion complex, the colour changed into dark yellowishbrown due to excitation of surface plasmon vibrations. Thus the colour change indicates that the formation of silver nanoparticles [37-39]. The silver nanoparticles colloid has been recorded as a function of time with silver nitrate as the reference [40].

The spectra peak indicated that the silver nanoparticles are poly dispersed. The Surface plasmon resonance (SPR) in the silver nanoparticles solution showed sharp peak at $425 \mathrm{~nm}$ throughout the reaction period indicating that the particles are dispersed in the solution [41]. The SPR band in UV-vis spectrum is due to electron oscillation around the surface of nanoparticles. The nanoparticles solution was stable for six months in the dark at room temperature although their slow degradation cannot be prevented [42].

The nanoparticles were spherical in shape with an average particle size of $38-68 \mathrm{~nm}$ with inter-particle distance determined by SEM analyser. This result indicated that the fruit peel extract of Citrus maxima worked effectively as a reductant and capping agent to synthesize and disperse the AgNPs. The SEM image of silver nanoparticles was due to interactions of hydrogen bond and electrostatic interactions between the bioorganic capping molecules bound to the AgNPs. The nanoparticles were not in direct contact even within the aggregates, indicating stabilization of the nanoparticles by a capping agent [43].

$\mathrm{XRD}$ is commonly used for determining the chemical composition and crystal structure of a material; therefore, detecting the presence of silver nanoparticles can be achieved by using XRD to examine the diffraction peaks of the extract. In our experiment the X-ray pattern of synthesized silver nanoparticles matches the FCC structure of the bulk silver with the broad peaks at 37.81, 44.01 and 64.36. These are corresponding to $111,200,311$ planes, respectively [44]. In addition to the Bragg peak representative of FCC silver nanocrystals, additional and yet unassigned peaks were also observed suggesting that the crystallization of bio-organic phase occurs on the surface of the silver nanoparticles [45]. The line broadening of the peaks is primarily due to small particle size. The XRD results of the fruit peel extract of Citrus maxima confirm that the silver nanoparticles formed by the reduction of $\mathrm{Ag}^{+}$ions and are crystalline in nature [46].

FTIR analysis confirmed that the bioreduction of $\mathrm{Ag}^{+}$ions to silver nanoparticles is due to the reduction by 
capping material of peel extract. Various study reported that the silver nanoparticles which make bind with the proteins present in the peel extract. The protein bind either in the free or carboxyl group [47]. Also, the polysaccharides, amides and fatty acids were responsible for the bio reduction, capping and stabilizing agents [48].

The antibacterial activity of synthesized silver nanoparticles was shown using fruit peel extract of Citrus maxima against grampositive bacteria (Staphylococcus aureus) and gram-negative bacteria (Escherichia coli). It has been reported that the AgNP's have the capacity to disturb the membrane and penetrate into the cell membrane, produce structural changes in the cell, and causes intracellular ATP leakage. Nanoparticles synthesized using fruit peel extract of Citrus maxima active against clinically isolated human pathogens [49].

The MTT assay is one of the important methods for analysis of cytotoxicity. It reveals the toxic materials from the cellular response and explains on apoptosis and the metabolic activities. The results showed that the high concentration exhibits the low cell viability on HeLa cell line. Thus the synthesized nanoparticles from the fruit peel extract of citrus maxima has a reduced cell viability and also increase in cell inhibition activity in HeLa cancer cell line. Fragmented DNA is one of the reasons for induction of apoptosis in HeLa cell line.
ROS plays a crucial role in triggering many cellular pathways which may cause cellular death, including cytokine activation and caspase activation. By changing the chemical structure of the nucleotide bases and the deoxyribosyl backbone also cause DNA damage [50].

\section{CONCLUSION}

The present work demonstrated an ecofriendly and convenient method used for synthesis of silver nanoparticles using fruit peel extract of Citrus maxima. It reduces silver ions into silver nanoparticles and has the potential to stabilize them. The Green synthesized nanoparticles were characterized by different techniques such as UV-visible spectroscopy, Fourier transform infrared spectroscopy, scanning electron microscopy, and X-ray diffraction and exhibited antibacterial activity. Our data suggest that silver nanoparticles synthesized from fruit peel extract of Citrus maxima can induce cytotoxic effects on HeLa cells, control the disease progression without affecting the normal cells and also inhibits the tumor cells. This green chemistry approach towards the synthesis of nanoparticles has many advantages such as Pharmaceutical, medical, and biotechnological applications. The silver nanoparticles synthesized from peel extract of Citrus maxima could be used for drug delivery and further this can be used as a 
therapeutic agent for cancer after the study of its molecular mechanism.

\section{ACKNOWLEDGMENTS}

We express our appreciation to the Centre for Bioscience and Nanoscience Research, Coimbatore for the services provided.

\section{CONFLICT OF INTEREST}

The authors declare that there is no conflict of interest.

\section{REFERENCES}

[1] Duhita G. Sant, Tejal R. Gujarathi, Shrikant R. Harne, et al.,: Adiantum philippense L. Frond Assisted Rapid Green Synthesis of Gold and Silver Nanoparticles. Journal of Nanoparticles: 2013

DOI: https://doi.org/10.1155/2013/182320 $\underline{0}$

[2] Darrell R. Boverhof, Christina M. Bramante, John H. Butala, Shaun F. Clancy, Mark Lafranconi, Jay West, Steve C. Gordon.: Comparative assessment of nanomaterial definitions and safety evaluation considerations. Regulatory Toxicology and Pharmacology: 2015. DOI:

https://doi.org/10.1016/j.yrtph.2015.06.00 1

[3] Neelu Chouhan.: Silver Nanoparticles: Synthesis, Characterization and Applications, Silver Nanoparticles Fabrication, Characterization and Applications. In: Khan Maaz, IntechOpen. intechopen: 2018.2 DOI: https://doi.org/10.5772/intechopen.75611
[4] Manzoor Ahmad Gatoo, Sufia Naseem, Mir Yasir Arfat, Ayaz Mahmood Dar, Khusro Qasim, and Swaleha Zubair.:Physicochemical Properties of Nanomaterials: Implication in Associated Toxic Manifestations. BioMed Research International: $2014 . \quad$ DOI: https://doi.org/10.1155/2014/498420

[5] Pirtarighat, S., Ghannadnia, M. \& Baghshahi, S. J Nanostruct. Chem: 2019 DOI: $\quad$ https://doi.org/10.1007/s40097018-0291-44

[6] S. Sinha, P. Pan, P. Chanda, and S. K. Sen, "Nanoparticles fabrications using ambient biological resource," Journal of Applied Biosciences. 2009; 19: 1113-1130

[7] S. Parveen, R. Misra, S.K. Sahoo, Nanoparticles: a boon to drug delivery, therapeutics, diagnostics and imaging. Nanomedicine: NBM: 2012. doi: https://doi.org/10.1016/j.nano.2011.05.016

[8] Bhattacharya, R.; Murkherjee, P.: Biological properties of "naked" metal nanoparticles. Adv. Drug Deliv. Rev: 2008; 60: 1284-1306

[9] Peralta-Videa, J.R., Huang, Y., Parsons, J.G. et al.: Nanotechnol. Environ. Eng: 2016.

DOI: https://doi.org/10.1007/s41204-016-0004$\underline{5}$

[10] Shah, Monaliben \& Fawcett, Derek \& Sharma, Shashi \& Tripathy, Suraj \& Poinern, Eddy.: Green Synthesis of Metallic Nanoparticles via Biological Entities. Materials. 2015; 8: 7278-7308

[11] Khandekar, S.V., Kulkarni, M., Devarajan, P.V.: Polyaspartic acid functionalized gold 
nanoparticles for tumor targeted doxorubicin delivery. J. Biomed. Nanotechnol. 2014; 10: 143-153

[12] H. A. Salam, R. Sivaraj, and R. Venckatesh, "Green synthesis and characterization of zinc oxide nanoparticles from Ocimum basilicum L. var. purpurascens Benth.-Lamiaceae leaf extract," Materials Letters. 2014 ;131:1618

[13] Singh, Priyanka \& Kim, Yu-Jin\& Zhang, Dabing\& Yang, Deok-Chun.: Biological Synthesis of Nanoparticles from Plants and Microorganisms. Trends in Biotechnology. 2016; 34(7): 588-599 (2016)

[14] Shakeel Ahmed, Mudasir Ahmad, Babu Lal Swami, Saiqalkram: A review on plants extract mediated synthesis of silver nanoparticles for antimicrobial applications: A green expertise. Journal of Advanced Research. 2016 DOI: https://doi.org/10.1016/j.jare.2015.02.007

[15] Das, R. K., Pachapur, V. L., Lonappan, L. et al. Nanotechnol. Environ. Eng. 2017. DOI: https://doi.org/10.1007/s41204-0170029-4

[16] Lee, Sang Hun, and Bong-Hyun Jun.: Silver Nanoparticles: Synthesis and Application for Nanomedicine. Int. journal of mol. sciences. 2019 doi: https://doi.org/10.3390/ijms20040865

[17] Shah, Monaliben et al:: Green Synthesis of Metallic Nanoparticles via Biological Entities. Materials (Basel, Switzerland). 2015. doi: https://doi.org/10.3390/ma81153777
[18] Iravani, $\mathrm{S}$ et al.: Synthesis of silver nanoparticles: chemical, physical and biological methods. Research in pharmaceutical sciences. 2014 ; 9: 385406

[19] Singh, Karishma.,Naidoo, Yougasphree., Mocktar, Chunderika., Baijnath, Himansu.,: Biosynthesis of silver nanoparticles using Plumbago auriculata leaf and calyx extracts and evaluation of their antimicrobial activities. Adv. Nat. Sci: Nanosci. Nanotechnol. 2018. DOI: http://dx.doi.org/10.1088/20436254/aad1a3TI

[20] Khandel, P., Yadaw, R.K., Soni, D.K. et $a l .:$ Biogenesis of metal nanoparticles and their pharmacological applications: present status and application prospects. J Nanostruct Chem. 2018 doi: https://doi.org/10.1007/s40097-018-0267$\underline{4}$

[21] Shankar, S.S., Rai, A., Ahmad, A., Sastry, M.: Rapid synthesis of $\mathrm{Au}, \mathrm{Ag}$, and bimetallic Au core-Ag shell nanoparticles using Neem (Azadirachta indica) leaf broth. J. Colloid Interface Sci. 2004; 275: 496-502

[22] Ram Prasad, "Synthesis of Silver Nanoparticles in Photosynthetic Plants," Journal of Nanoparticles, 2014. DOI: https://doi.org/10.1155/2014/963961

[23] Kwatra Shubhika.: Nanotechnology and medicine - The upside and the downside. Int. J. Drug Dev. \& Res., 2013; 5(1): 1-10

[24] Zhang XF, Liu ZG, Shen W, Gurunathan S.: Silver Nanoparticles: Synthesis, Characterization, Properties, Applications, 
and Therapeutic Approaches. Int $\mathrm{J}$ Mol

Sci. 2016; 17(9): 1534 doi: https://doi.org/10.3390/ijms17091534

[25] Jayanta Kumar Patra and Kwang-Hyun Baek,:Green Nanobiotechnology: Factors Affecting Synthesis and Characterization Techniques. Journal of Nanomaterials.. 2014.

DOI: https://doi.org/10.1155/2014/417305

[26] Burdușel, Alexandra-Cristina et al.: Biomedical Applications of Silver Nanoparticles: An Up-to-Date Overview. Nanomaterials. 2018 doi: https://doi.org/10.3390/nano8090681

[27] Chanel Tri Handoko, Adri Huda and FakhiliGulo,: Synthesis Pathway and Powerful Antimicrobial Properties of Silver Nanoparticle: A Critical Review. Asian Journal of Scientific Research. 2019 DOI: http://dx.doi.org/10.3923/ajsr.2019.1.17

[28] Qing Y, Cheng L, Li R, et al:: Potential antibacterial mechanism of silver nanoparticles and the optimization of orthopedic implants by advanced modification technologies. Int $\mathrm{J}$ Nanomedicine. $2018 . \quad$ doi: https://doi.org/10.2147/IJN.S1651255

[29] Dakal TC, Kumar A, Majumdar RS, Yadav V.: Mechanistic Basis of Antimicrobial Actions of Silver Nanoparticles. Front Microbiol. 2016. doi: https://doi.org/10.3389/fmicb.2016.01831

[30] Sirisomboon P, Theamprateep C.: Physicochemical and Textural Properties of Pomelo (Citrus maxima Merr. cv. Kao Nam Pueng) Fruit at Preharvest,
Postharvest and During the Commercial Harvest Period. Philipp Argic. 2012; 95(1): 43-52

[31] Demir S., Aliyazicioglu Y., Turan I. Antiproliferative and proapoptotic activity of Turkish propolis on human lung cancer cell line. Nutr. Cancer. 2016; 68: 165-172

[32] dos Santos H.M., Júnior, Oliveira D.F., de Carvalho D.A. Evaluation of native and exotic Brazilian plants for anticancer activity. J. Nat. Med. 2010; 64: 231-238.

[33] Vijaylakshmi P, Radha R. An overview: Citrus maxima. J Phytopharmacol. 2015; 4(5): 263-7

[34] Sen SK, Haldar PK, Gupta M, Mazumder UK, Saha P, Bala A.: Antitumor activity of Citrus maxima (Burm.) Merr. Leaves in Ehrlich's ascites carcinoma celltreated mice. ISRN Endocrinology. 2011;1-7

[35] Ponarulselvam S, Panneerselvam C, Murugan K, Aarthi N, Kalimuthu K, Thangamani S.: Synthesis of silver nanoparticles using leaves of Catharanthus roseus Linn. G. Don and their antiplasmodial activities. Asian Pac J Trop Biomed. 2012. doi: https://doi.org/10.1016/S22211691(12)60100-2

[36] Kumar, P., Selvi, S.S., Govindaraju, M.: Seaweed-mediated biosynthesis of silver nanoparticles using Gracilaria corticata for its antifungal activity against Candida spp. Appl. Nanosci. 3, 495-500 (2013)

[37] Shankar SS, Rai A, Ankamwar B, et al. Biological synthesis of triangulargoldnanoprisms. Nat Mater. 2004; 3(7): 482-488 
[38] Shankar SS, Rai A, Ahmad M, et al. Rapid synthesis of $\mathrm{Au}, \mathrm{Ag}$, and bimetallic $\mathrm{Au}$ Core-Ag shell nanoparticles using Neem (Azadirachta indica) leaf broth. $J$ Colloid Interface Sci. 2752004; (2): 496-502

[39] Panigrahi, Tamasa.: Synthesis and characterization of silver nanoparticles using leaf extract of Azadirachta indica. Rourkela. Department of Life Science. Orissa: National institute of Technology. 2013

[40] Arockia John Paul, J., Karunai Selvi, B., Karmegam, N. Appl Nanosci 2015. DOI: https://doi.org/10.1007/s13204-014-0397-z

[41] Jain D, Daima HK, Kachiwaha S, Kotheri SL.: Synthesis of plant mediated silver nanoparticles using papaya fruit extract and evolution of their antimicrobial activities. Dig J Nanomater Biostruct. $2009 ; 4: 557-56$

[42] Sainath Babu, Michelle O. Claville \& Kesete Ghebreyessus.: Rapid synthesis of highly stable silver nanoparticles and its application for colourimetric sensing of cysteine, Journal of Experimental Nanoscience. (2015). DOI: https://doi.org/ $\underline{10.1080 / 17458080.2014 .994680}$

[43] Preetha Devaraj, Prachi Kumari, Chirom Aarti, and Arun Renganathan, :Synthesis and Characterization of Silver Nanoparticles Using Cannonball Leaves and Their Cytotoxic Activity against MCF-7 Cell Line. Journal of Nanotechnology, 2013. https://doi.org/10.1155/2013/598328

[44] de Jesús Ruíz-Baltazar, Á., Reyes-López, S.Y., Larrañaga, D., Estévez, M., Pérez,
R.: Green synthesis of silver nanoparticles using a Melissa officinalis leaf extract with antibacterial properties. Results Phys.2017; 7: 2639-2643

[45] Mahendran Vanaja, Gurusamy Annadurai.: Coleus aromaticus leaf extract mediated synthesis of silver nanoparticles and its bactericidal activity. Applied Nanoscience.2013; 3(3):217-223. (2013)

[46] N. Savithramma, M. Linga Rao, and P. Suvarnalatha Devi,: Evaluation of antibacterial efficacy of biologically synthesized silver Nanoparticles using stem barks of Boswellia ovalifoliolata Bal. and Henry and Shoreatum buggaia Roxb. Journal of Biological Sciences. 2011; 11(1): 39-45

[47] A. Gole, P. Chaudhari, J. Kaur, M. Sastry, Langmuir.: Bioinorganic Chemistry and Applications 2018.2 DOI: https://doi.org/10.1155/2018/7879403

[48] Neveen Abdel-Raouf, Nouf Mohammad Al-Enazi, Ibraheem Borie Mohammad Ibraheem, Reem Mohammed Alharbi, Manal Mohammed Alkhulaifi,: Biosynthesis of silver nanoparticles by using of the marine brown alga Padina pavonia and their characterization, Saudi Journal of Biological Sciences. 2019. DOI: https://doi.org/10.1016/j.sjbs.2018.01.007

[49] Hajipour, M.J., Fromm, K.M., Ashkarran, A.A., de Aberasturi, D.J., de Larramendi, I.R., Rojo, T., Serpooshan, V., Parak, W.J., Mahmoudi, M.: Antibacterial properties of nanoparticles. Trends Biotechnol. 2012; 30: 499-511 
[50] Krishnasamy, L., P. Ponmurugan, K. Jayanthi, and V. Magesh. "Cytotoxic, Apoptotic Efficacy of Silver Nanoparticles Synthesized from Indigofera Aspalathoids". International Journal of Pharmacy and Pharmaceutical Sciences. 2014; 6(8): 245-8 